\title{
Organic versus integrated apple growing: I. differences in soil and leaf parameters
}

\author{
Nagy, P.T., Szabó, Z., Nyéki, J., Gonda, I. \& Holb, I. \\ University of Debrecen, Centre of Agricultural Sciences, Faculty of Agronomy, Böszörményi u. 138. \\ Debrecen, H-4032, Hungary
}

\begin{abstract}
Summary: The aim our study was to establish whether significant differences in nutrients uptake and quality of soil and leaf exist between organic and integrated grown apples. The study was performed at the orchard Fruit Research Station, University of Debrecen, at DebrecenPallag during 2002-2004. Macro and micro elements were measured in soil and plant samples. Analyses of variance of soil nitrogen data indicated highly significant differences between the two management systems $(P<0.001)$ for each examined nitrogen fraction. Analyses of variance of soil phosphate data indicated significant differences $(P<0.05)$ between the two management systems for orto- $\mathrm{PO}_{4}{ }^{3-}$ contents. Our data indicated that highly significant differences between the two management systems $(P<0.001)$ for magnesium, copper, and zinc; while significant differences between the two management systems was at $P=0.007$ for calcium. Three year's data of leaf phosphorus, sulphur and zinc were not shown significant differences between production systems. Nevertheless manganese and copper contents of leaves were higher in the organic orchard compared to the integrated one.
\end{abstract}

Key words: integrated, organic, leaf and soil analyses, N, P, K, Mg, Ca, S, Cu, Mn, Zn

\section{Introduction}

Worldwide demand for organic food products continues to expand rapidly especially developed countries. Accordingly in recent years consumers demand is continuously increasing in Hungary as well. More and more consumers are thus prepared to pay premium prices for organic fruits thanks to the perception that organic products are safe, clean, more nutritious, healthy better-tasting and environmentally friendlier than conventional fruits. It also means that nowadays there is an increasing interest in environmental friendly growing systems and attention has also been paid to the environmental impacts of natural and artificial fertilizations in fruit growing.

As a result, numerous studies have sought to determine whether significant differences in yield and quality truly exist between organic, integrated and conventionally growing fruits (Worthington, 2001; Lester, 2006).

But a common thread to compare these growing systems is the huge variability in the available data. In most cases, it is clear that variability stems from the inability to control or standardize the basic environmental factors affecting fruit development and yield such as soil physical, biological and chemical properties (Lester, 2006). Moreover, differences in fruit nutrition, water management, pest practices, varieties, fruit maturity and harvest dates, pre- and postharvest handling can individually and collectively contribute to the observed variability and opposing conclusions.

From this respect our experimental site is very excellent to carry out comparative studies. Because the effects of some above mentioned factors can be eliminate in our study.
Accordingly the aim our study is to establish whether significant differences in nutrients uptake and quality exist between organic and integrated grown apples.

\section{Material and methods}

\section{Characteristics of examined apple orchard}

The study was performed at the orchard Fruit Research Station (University of Debrecen), at Debrecen-Pallag during 2002-2004. The 1 ha orchard was planted in 1997 with 39 apple cultivars, grafted on M26 rootstock. Spacing between and within rows was $4 \times 1.5 \mathrm{~m}$. The orchard was divided into integrated and organic management systems following to the integrated and organic production guidelines, respectively. Cultivars were planted in 7-tree plots and replicated three times in both management systems. Integrated orchard part consists of 9, while organic consists of 8 rows, labelled from A to $\mathrm{L}$ per line. Organic and integrated orchard part was separated by hedgerow (Figure 1).

Selected seven cultivars (cv. 'Jonagold', 'Mutsu', 'Idared', 'Red Elstar', 'Egri piros', 'Remo' 'Reka') were positioned by randomize way.

\section{Nutrition management of experimental site}

Nutrition supply was maintained with synthetic fertilizers in the integrated orchards part. An NPK complex fertilizer (Péti Kevert NPK Mütrágya, Nitrogénművek $\mathrm{GmbH}$, Pétfürdő, Hungary), at a dosage of $200 \mathrm{~kg} \mathrm{ha}^{-1}$ active 


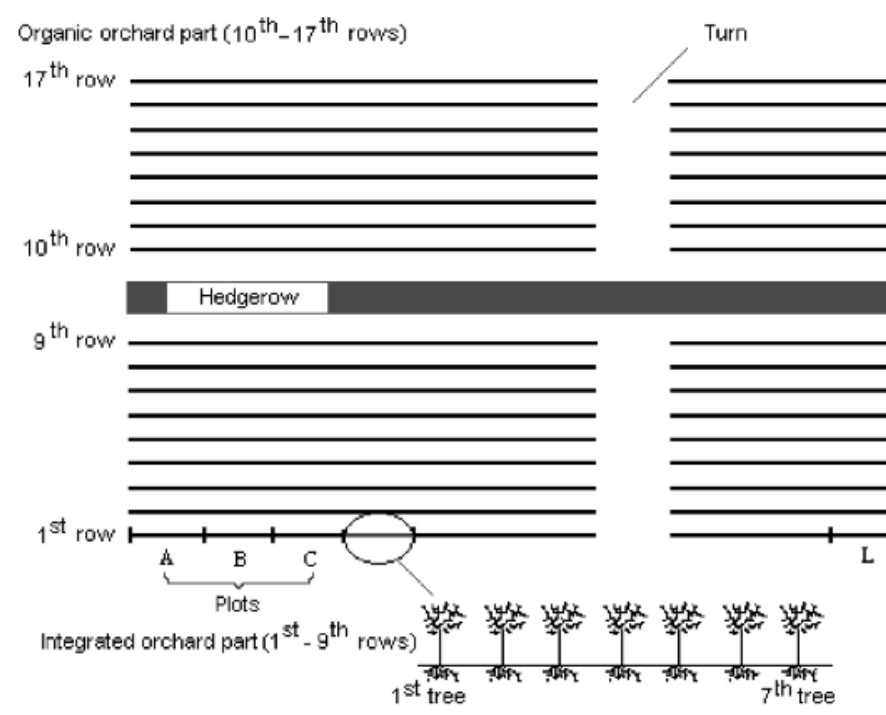

Figure 1: Field set of examined apple orchard

ingredient with 10:15:15 NPK ratio, was applied to the soil at the beginning of March in 2002 and 2003. Additional fertilization was made in mid-April of 2002 and 2003 with $\mathrm{NH}_{4} \mathrm{NO}_{3}$ (Ammónium nitrát, Nitrogénmüvek $\mathrm{GmbH}$, Pétfürdö, Hungary) at a dosage of $40 \mathrm{~kg} \mathrm{ha}^{-1} \mathrm{NH}_{4} \mathrm{NO}_{3}$ active ingredient. Moreover, beet potash, $4 \mathrm{t} \mathrm{ha}^{-1}$ was used in the integrated area in 2002.

In the organic orchard part, stable manure, $30 \mathrm{t} \mathrm{ha}^{-1}$ were applied to the soil in 2001 and 2003.

\section{Soil sampling}

Soil was sampled from each 7-tree plot of examined apple cultivars from both the integrated and the organic orchard blocks. Three samples were taken from each plot, one from the middle and one from both edges of the plots by leaving $1 \mathrm{~m}$ at both sides. As the root system was most intense in the upper layer of the soil, soil samples were taken from 0-20 cm layers of the soil by using a manual soil sampling equipment according to international and Hungarian soil sampling guidelines for fruit orchards (Jackson, 1958; MSZ-08 0202-77). Sampling was performed at the beginning and the end of the vegetation period on 16 April and 23 October and 29 April and 16 October in 2002 and 2003, respectively.

Sampling was performed at the end of the vegetation period, on 16 October in 2008.

Soil sample as an untreated control were also taken from the neighbouring arable field.

\section{Quantification of soil parameters}

The soil samples were dried outdoors in an airy place in a $1-1.5 \mathrm{~cm}$ layer, then the soil was sieved through a sieve of $2 \mathrm{~mm}$ hole size, homogenized and stored in plastic boxes until the examination. Soil $\mathrm{pH}$ was determined from soil solution made by $0.01 \mathrm{M} \mathrm{CaCl}_{2}$. Plasticity index $\left(\mathrm{K}_{\mathrm{A}}\right)$ and humus content was measured according to Hungarian guideline (MSZ 20135:1999). Nitrogen forms of each soil sample were quantified according to Houba et al., 1986. Briefly, $5 \mathrm{~g}$ soil in a 50-ml 0.01 $\mathrm{M} \mathrm{CaCl}_{2}$ extractant was shaken for $2 \mathrm{hrs}$ and then $\mathrm{NO}_{3}^{-}-\mathrm{N}, \mathrm{NH}_{4}^{+}-\mathrm{N}$, organic-N and total soluble- $\mathrm{N}$ were determined by the CFA method. For extracting the available phosphorus and potassium content of soils, ammonium-lactate solution (so called AL extractant) was used, then the amount of phosphorus was quantified colorimetrically with the phospomolybdovanadate method (MSZ 20135:1999) using a spectrophotometer (Metertech VIS SP-850 Plus; Metertech Inc., Taipei, Taiwan). Potassium was quantified by flame atom emission spectrophotometry method (MSZ 20135:1999), using an Unicam SP90B Series 2 Atomic Absorption/Emission Spectrophotometer (PYE Unicam, England). For determining $\mathrm{Ca}, \mathrm{Mg}, \mathrm{Mn}$, $\mathrm{Cu}$ and $\mathrm{Zn}$ contents of soil Lakanen-Erviö solution (LE) was used (Lakanen Erviö, 1971). Soil Ca, Mg, Mn, Cu and $\mathrm{Zn}$ contents were quantified by flame atomic absorption spectrophotometry using a SpectrAA-10 Plus spectrophotometer (Varian Australia Pty Ltd. Mulgrave, Australia) (MSZ 20135:1999).

\section{Plant sampling}

The same seleted cultivars form the same 7-tree plots were used for plant sampling as for soil sampling. Leaves were taken from all trees of each 7-tree plot at the stage of full blooming and later at the standard sampling time (second half of July). At each sampling date, 8-10 healthy leaves were taken from the mid-third portion of extension shoots current year were collected in each selected tree, following the international and Hungarian plant sampling guidelines for fruit orchards (Stiles and Reid, 1966; MI-08 0468-81).

\section{Quantification of leaf samples}

Leaf samples were dried firstly outdoors in an airy place then in a well-ventilated drying oven for $6 \mathrm{hrs}$ at $70^{\circ} \mathrm{C}$, the whole sampled material was finely grounded and homogenized. Samples were then stored in paper bags in a dark and dry place until use. Nitrogen content of leaves was determined from homogenized samples directly using the dry combustion method according to Nagy (2000) using an Elementar Vario EL analyser (Elementar Analysensysteme GmbH, Hanau, Germany). For determining phosphorus and potassium contents of leaves, first homogenized leaf samples ( $0.5 \mathrm{~g}$ each sample) were digested with cc. $5 \mathrm{ml} \mathrm{H}_{2} \mathrm{SO}_{4}$ and $5 \mathrm{ml} \mathrm{H}_{2} \mathrm{O}_{2}$ in a heating block digestor, at $220 \mathrm{C}$ for $2 \mathrm{hrs}$. Then phosphorus was quantified colorimetrically with the phospomolybdovanadate method using a spectrophotometer (Metertech VIS SP-850 Plus; Metertech Inc., Taipei, Taiwan). Leaf $\mathrm{K}$ was determined by flame atom emission spectrophotometry and $\mathrm{Ca}, \mathrm{Mg}, \mathrm{Mn}, \mathrm{Cu}$ and $\mathrm{Zn}$ contents of leaves were quantified by flame atomic absorption method as described for soil samples. 


\section{Results and discussion}

\section{Results of soil examination}

Orchard soil type was brown forest soil with alternated layer of clay ("Kovárvány"), being relatively poor in colloids, macronutrients and humus content (Table 1).

The plasticity index according to Arany $\left(\mathrm{K}_{\mathrm{A}}\right)$ was 28. Total carbon and nitrogen content was 0.34 and $0.043 \%$ (dm.) Salinity of soil was approx. $0.002 \%$. The $\mathrm{pH}$ of soil was slightly acidic. Higher value was measured in soil samples of the integrate orchard part than organic one due to the different fertilization management and applied lime addition in integrated part.

Table 1. Soil analytical results of examined orchard parts (2002-2004, average)

\begin{tabular}{|c|c|c|}
\hline & Integrated & Organic \\
\hline $\mathrm{K}_{\mathrm{A}}{ }^{*}$ & \multicolumn{2}{|c|}{28} \\
\hline $\mathrm{pH}\left(0,01 \mathrm{M} \mathrm{CaCl}_{2}\right)$ & 5.49 & 5.13 \\
\hline Humus (\%) & 0.93 & 0.75 \\
\hline $\mathrm{NO}_{3}{ }^{-}-\mathrm{N}\left(0,01 \mathrm{M} \mathrm{CaCl}_{2}\right)(\mathrm{mg} / \mathrm{kg})$ & 3.63 & 1.00 \\
\hline $\mathrm{NH}_{4}{ }^{+}-\mathrm{N}\left(0,01 \mathrm{M} \mathrm{CaCl}_{2}\right)(\mathrm{mg} / \mathrm{kg})$ & 1.55 & 0.81 \\
\hline Organic $\mathrm{N}\left(0,01 \mathrm{M} \mathrm{CaCl}_{2}\right)(\mathrm{mg} / \mathrm{kg})$ & 3.67 & 2.90 \\
\hline $\mathrm{PO}_{4}{ }^{3-}\left(0,01 \mathrm{M} \mathrm{CaCl}_{2}\right)(\mathrm{mg} / \mathrm{kg})$ & 8.99 & 4.76 \\
\hline $\mathrm{K}(0,01 \mathrm{M} \mathrm{CaCl})_{2}(\mathrm{mg} / \mathrm{kg})$ & 201 & 168 \\
\hline $\mathrm{Ca}(\mathrm{LE})(\mathrm{mg} / \mathrm{kg})$ & 579 & 451 \\
\hline $\operatorname{Mg}(\mathrm{LE})(\mathrm{mg} / \mathrm{kg})$ & 54.9 & 87.4 \\
\hline Mn (LE) (mg/kg) & 62.4 & 62.3 \\
\hline $\mathrm{Cu}(\mathrm{LE})(\mathrm{mg} / \mathrm{kg})$ & 3.90 & 3.48 \\
\hline $\mathrm{Zn}(\mathrm{LE})(\mathrm{mg} / \mathrm{kg})$ & 3.07 & 1.78 \\
\hline
\end{tabular}

*Plasticity index according to Arany

Analyses of variance of soil nitrogen data indicated highly significant differences between the two management systems $(P<0.001)$ for each examined nitrogen fraction; however, significant differences among years and interactions among variables were not observed for any nitrogen fraction (data not shown). Nitrate nitrogen, ammonium nitrogen and soluble organic nitrogen in the soil were significantly higher $(\mathrm{P}=0.05)$ in the integrated orchard blocks compared to the organic blocks. It was accordance with the results of yields. Significant amount of easily soluble organic nitrogen fraction was pointed out that organic production can be use in sandy soils provided that the efficiency of nutrients should be increased by improving soil properties.

Similarly to our study, Glover et al., (2000) also demonstrated that nitrate nitrogen and total soluble nitrogen of soil sampled from $0-20 \mathrm{~cm}$ depth were significantly higher in integrated orchards compared to the organic one.

Analyses of variance of soil phosphate data indicated significant differences $(P<0.05)$ between the two management systems for orto- $\mathrm{PO}_{4}^{3-}$ contents.
Analyses of variance of soil potassium content indicated weak differences between the two management systems. Potassium content of the integrated soil samples was slightly higher compared to that of the organic one (Table 1). Our data on potassium content showed that both integrated and organic orchard parts contained a major amount of potassium in spite of soil properties with poor colloid content.

Our data indicated that highly significant differences between the two management systems $(P<0.001)$ for magnesium, copper, and zinc; while significant differences between the two management systems was at $P=0.007$ for calcium. Years had no significant effect for any soil elements and manganese data indicated no significant differences among years, management systems.

Results obtained indicated that seasonal variability of available elements in the soil was higher in the organic orchards compared with integrated one (data not shown). Copper content of the integrated soils was significantly lower $(P=0.05)$ compared to that of the organic one (Table 1$)$. This is probably due to more frequent copper uses (as a fungicide) in an organic orchard than in integrated one. Manganese content was similar in both the integrated and the organic soils. In both the integrated and organic orchard blocks, the obtained data on copper, zinc and manganese content correspond to the values characteristic to sandy soil with low humus content and pH value (Holb et al., 2009).

Soil analytical results corresponded to the differences of nutrient supply of fruit productions. Data obtained pointed out that organic farming under unfavourable conditions could not based on simply organic fertilization. Required yield can be received only soil improving nutritional management.

\section{Results of leaf examination}

Based on leaf diagnostic results established that studied growing ways not affected the dynamics of macro and microelement uptake of examined seven cultivars.

Moreover, nitrogen, potassium, calcium and magnesium contents of leaves were higher in the integrated orchard compared to the organic one in all years, cultivars and sampling dates (data shown only at standard sampling time (Table 2).

Three year's data of leaf phosphorus, sulphur and zinc were not shown significant differences between production systems.

Nevertheless manganese and copper contents of leaves were higher in the organic orchard compared to the integrated one

Copper content of leaves was in the 'optimal' range of nutrient supply category which can be explained by the relatively high $\mathrm{Cu}$ content of soil follows from the frequent use of copper sprays against diseases and pests (Holb et al., 2009).

Moreover, our results pointed out although seasonal patterns of $\mathrm{Ca}, \mathrm{Mg}, \mathrm{S}$ and some micronutrients were similar in both growing systems, availability of these nutrients were always more stable in the integrated orchard than in the organic one. 
Table 2. Nutrient contents in apple leaves

(Pallag, 2002-2004, averages of cultivars at standard sampling time)

\begin{tabular}{|l|c|c|}
\hline \multicolumn{1}{|c|}{ Nutrient content } & Integrated & Organic \\
\hline $\mathrm{N}(\%)$ & 2.30 & 2.14 \\
\hline $\mathrm{P}(\%)$ & 0.19 & 0.20 \\
\hline $\mathrm{K}(\%)$ & 1.33 & 1.14 \\
\hline $\mathrm{Ca}(\%)$ & 1.38 & 1.46 \\
\hline $\mathrm{Mg}(\%)$ & 0.37 & 0.41 \\
\hline $\mathrm{S}(\%)$ & 0.21 & 0.21 \\
\hline $\mathrm{Mn}(\mathrm{mg} / \mathrm{kg})$ & 66.54 & 73.12 \\
\hline $\mathrm{Zn}(\mathrm{mg} / \mathrm{kg})$ & 23.96 & 23.23 \\
\hline $\mathrm{Cu}(\mathrm{mg} / \mathrm{kg})$ & 4.08 & 6.88 \\
\hline
\end{tabular}

Beside absolute element concentrations binary ratios of them were also investigated. Our assumption is that these ratios can provide a better indication of nutritional status than conventional sufficiency range approaches. It has been suggested that using these ratios minimize the effects of dilution or concentration due to dry matter and age factors and better evaluates possible nutritional interactions. The most frequently used ratios $(\mathrm{N} / \mathrm{K}, \mathrm{N} / \mathrm{P}, \mathrm{N} / \mathrm{Ca}, \mathrm{K} / \mathrm{Ca}, \mathrm{K} / \mathrm{Mg}$, $\mathrm{Ca} / \mathrm{Mg}$ and $\mathrm{Cu} / \mathrm{Zn} / \mathrm{Mn}$ ) were calculated (Table 3).

Nutrient ratios were favourable in integrated orchard part than organic one, which pointed out the balanced and harmonic nutrient supply conditions in this orchard part (Table 3).

Table 3. Nutrient ratios in apple leaf

(Pallag, 2002-2004, averages of cultivars at standard sampling time)

\begin{tabular}{|l|c|c|c|}
\hline Nutrient ratios & Integrated & Organic & Optimal \\
\hline $\mathrm{N} / \mathrm{K}$ & 1.74 & 2.01 & 1.76 \\
\hline $\mathrm{N} / \mathrm{P}$ & 12.10 & 11.20 & 14.40 \\
\hline $\mathrm{N} / \mathrm{Ca}$ & 1.67 & 1.56 & 1.53 \\
\hline $\mathrm{K} / \mathrm{Ca}$ & 0.97 & 0.79 & 0.87 \\
\hline $\mathrm{K} / \mathrm{Mg}$ & 3.60 & 2.80 & 3.90 \\
\hline $\mathrm{Ca} / \mathrm{Mg}$ & 3.72 & 3.62 & 4.50 \\
\hline $\mathrm{Cu} / \mathrm{Zn} / \mathrm{Mn}$ & $\sim 1: 6: 16$ & $\sim 1: 3: 11$ & $\sim 1: 3: 1$ \\
\hline
\end{tabular}

Direct evidence was found that the applied plant protection practice have an effect on nutrient uptake and following of this the ratio of nutrient in leaves.

Due to the higher leaf $\mathrm{Cu}$ content in organic apple leaves, the $\mathrm{Cu}: \mathrm{Zn}: \mathrm{Mn}$ triple ratio was closer the optimal value in organic than integrated samples. From results it was established that the ability of nutrient supply of integrated fruit production is balanced and more stable than organic production in the vegetation period.

In conclusion, based on our results it was found that the year and production system significantly affected all examined leaf nutrient concentrations. Obtained leaf analytical results depended on cultivars. But the effect between production systems was inconsistent sometimes.

Moreover, our results suggested that better mobility of artificial fertilizers in integrated orchards provided higher macronutrient uptake than organic orchards where only natural nutrient sources are allowed. This study also demonstrated that the lower nutrient content of soil and also the generally poorer uptake of $\mathrm{N}, \mathrm{P}$ and $\mathrm{K}$ nutrients in organic apple orchards resulted in higher production risk in the organic apple orchards compared with integrated ones. This indicates that a more efficient nutrient supply is needed for the organic management system.

\section{Acknowledgements}

Thanks to OM-00042/2008 project for financial assistance. The study was supported by the NKTH programme (OM-00227/2008) and by the research programme of OTKA (K 78399) as well as by a János Bolyai Research Fellowship.

\section{Literature cited}

Glover, J.D., Reganold, J.P. \& Andrews, P.K. (2000): Systematic method for rating soil quality of conventional, organic, and integrated apple orchards in Washington State. Agr. Ecosyst. Environ., 80: 29-45.

Holb I.J., Gonda I., Vágo I. \& Nagy P. T. (2009): Seasonal Dynamics of Nitrogen, Phosphorus, and Potassium Contents of Leaf and Soil in Environmental Friendly Apple Orchards. Communications in soil science and plant analysis 40, 1-6: Sp. Iss. SI: 694-705.

Houba, V.J.G., Novozamsky, I., Huijbregts, A.W.M. \& Lee, van der, J.J. (1986): Comparison of soil extractions by $0.01 \mathrm{CaCl}_{2}$ by EUF and by some conventional extraction procedures. Plant and Soil, 96: 433-437.

Jackson, M.L. (1958): Soil Chemical Analysis; Prentice Hall Inc.: Englewood Cliffs, UK, 1958; 546 pp.

Lakanen, E. \& Erviö, R.A. (1971): Comparison of eight extractants for determination of plant available micronutrients in soil. Acta Agr. Fennenica, 123: 223-232.

Lester, G. E. (2006): Organic versus conventionally grown produce:quality differences, and guidelines for comparison studies. Hortscience, 41 (2): 296-299.

MSZ-08 0202-77: Sampling soils for management purposes in agriculture. Hungarian Standards Institution. Ministry of Agriculture. Budapest (in Hungarian)

MI-08 0468-81: Plant analyses. Orchards. Sampling, preparation of samples, storing of samples. Hungarian Standards Institution. Ministry of Agriculture. Budapest (in Hungarian)

MSZ 20135:1999: Determination of the soluble nutrient element content of the soil. Hungarian Standards Institution. Budapest (in Hungarian).

Nagy, P.T. (2000): Application of an element analyser for soil and plant analyses (dry combustion method). Agrokémia és Talajtan 49: 521-534. (in Hungarian with English summary)

Stiles, W.C., Reid \& W.S. (1966): Orchard Nutrition Management; Cornell Cooperative Extension: Geneva, NY, Information Bull., 219.

Worthington, V. (2001): Nutritional quality of organic versus conventional fruits, vegetables and grains. J. Alt. Complem. Med., 7: 161-173. 